\title{
EVALUATION OF A CAPILLARY ELECTROPHORESIS METHOD FOR ROUTINE DETERMINATION OF VARENICLINE TARTRATE IN QUALITY-CONTROL LABORATORIES
}

\author{
Mustafa Çelebier, Engin Koçak, Sacide Altınöz* \\ Hacettepe University, Faculty of Pharmacy, Department of Analytical Chemistry, 06100 Ankara, Turkey \\ *saltinoz@hacettepe.edu.tr
}

In this study, analyses were carried out on a fused-silica capillary (i.d. $50.0 \mu \mathrm{m}$, total length 48.5 $\mathrm{cm}$, and effective length $40.0 \mathrm{~cm}$ ) in normal mode by applying a voltage of $20 \mathrm{kV}$. Sample injections were made in hydrodynamic mode over $7 \mathrm{~s}$ under a pressure of $50 \mathrm{mbar}$. The capillary temperature was set at $35^{\circ} \mathrm{C}$ and the detection was performed at a wavelength of $205 \mathrm{~nm}$. The background electrolyte was 40 $\mathrm{mM}$ citrate buffer at $\mathrm{pH} 6.0$ and the internal standard was labetalol hydrochloride. The total analysis time was shorter than 5 minutes. The method was validated according to the International Conference on Harmonization (ICH) guidelines, and the method was found to be linear, precise, accurate, specific, robust, and rugged. The linearity range was found to be $1.0-60.0 \mu \mathrm{g} \mathrm{ml}^{-1}$ and the limit of detection and quantitation were 0.5 and $1.0 \mu \mathrm{g} \mathrm{ml}^{-1}$, respectively. The developed method was proposed for quality-control laboratories.

Keywords: capillary electrophoresis; varenicline tartrate; analytical method validation; pharmaceutical dosage forms; quality control

\section{ЕВАЛУАЦИЈА НА МЕТОДОТ НА КАПИЛАРНА ЕЛЕКТРОФОРЕЗА ЗА РУТИНСКО ОПРЕДЕЛУВАЊЕ ВАРЕНИКЛИН ТАРТАРАТ ВО ЛАБОРАТОРИИ ЗА КОНТРОЛА НА КВАЛИТЕТ}

Во оваа студија извршена е анализа на капилара од фузирана силика (в.д. $50.0 \mu \mathrm{m}$, должина $48,5 \mathrm{~cm}$ и ефективна должина 40,0 cm) во нормален мод со примена на напон од $20 \mathrm{kV}$. Инјектирањето на примероците беше вршено во хидродинамичен мод во времетраење од $7 \mathrm{~s}$ под притисок од 50 mbar. Температурата на капиларата беше на $35{ }^{\circ} \mathrm{C}$ и детекцијата беше вршена на бранова должина од $205 \mathrm{~nm}$. Беше користен $40 \mathrm{mM}$ цитратен пуфер на $\mathrm{pH} 6.0$ како електролит на матрицата, додека како внатрешен стандард беше користен лабеталол-хидрохлорид. Вкупното време на анализа беше под 5 минути. Методот беше валидиран според препораките на Меѓународната конференција за хармонизација (International Conference on Harmonization - ICH) при што беше утврдено дека методот е линеарен, прецизен, точен, специфичен, робустен и отпорен. Линеарниот опсег изнесува 1.0-60.0 $\mu \mathrm{g} \mathrm{ml}^{-1}$, додека прагот на детекција и квантификација изнесуваа соодветно 0.5 и $1.0 \mu \mathrm{g} \mathrm{ml}^{-1}$. Разработениот метод е предложен за лаборатории за контрола на квалитет.

Клучни зборови: капиларна електрофореза; вареницилин тартарат; валидација на аналитички метод; фармацевтско дозирање; контрола на квалитет

\section{INTRODUCTION}

Varenicline is used together with education and counseling to help people stop smoking; it be- longs to a class of medication called smoking cessation aids. Varenicline blocks the pleasant effects of nicotine (from smoking) on the brain. The nicotinic acetylcholine receptor (nAChR) plays an im- 
portant role in nicotine dependence, alcohol consumption, and induced cocaine cravings. Stimulation of the nAChR has been found to alter and modulate cell firing in brain areas that are important for the maintenance of drug dependence. Varenicline tartrate (VT) was the first partial agonist of nAChR to be approved. Specifically, VT is a partial agonist of the $\alpha 4 \beta 2$ subtype of the nAChR and a full agonist of $\alpha 7 \mathrm{nAChR}$ [1-3]. The chemical structure of VT is given in Figure 1 [4].

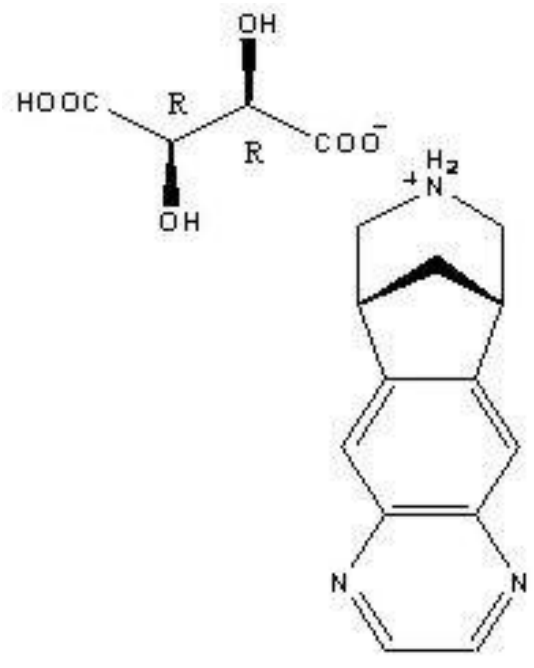

Fig. 1. Chemical structure of VT

In this study we aimed to develop a precise and accurate capillary electrophoresis (CE) method for the determination of VT in pharmaceutical dosage forms. Using internal standards (IS) is a key point in improving precision and accuracy; therefore, the VT and IS (Labetalol hydrochloride) were positively charged and separated in order to be analyzed within 5 minutes by using citrate buffer (pH 6.0) as the background electrolyte (BGE). There is no organic solvent used during the analysis, including the procedure for preparing standard stock solutions. Thus, the proposed CE method might be evaluated as a good and "green" alternative for the routine determination of VT compared to other automated analytical techniques such as high-performance liquid chromatography (HPLC). VT has been analyzed by HPLC [5-10], ultraviolet (UV) spectrophotometry [11], and electrochemistry [12]. Although, a new CE method [13] has recently been reported for the determination of VT in pharmaceutical dosage forms, the developed method presented herein differs from the previously reported one by the type of internal standard and BGE used. A thorough method optimization process was carried out and a wider linearity range was achieved $\left(1.0-60.0 \mu \mathrm{g} \mathrm{ml}^{-1}\right)$ compared to the previously reported one $\left(1.0-16.0 \mu \mathrm{g} \mathrm{ml}^{-1}\right)$. It is reported that poor quantitative reproducibility substantially limits the practical implementation of CE separations in analysis. The principal sources of variance in the observed peak areas are found in the irreproducible flow rates, which influence the on-column detector response, and inconsistent injection volumes or amounts [14]. Therefore, the method developed in this study was fully validated, including robustness and ruggedness testing. Another reported method for the determination of varenicline in human urine also used CE coupled with tandem mass spectrometry (MS) [15]. However, the aim of this study is to develop a simple and rapid CE method. CE-MS techniques need complex instrumentation and, for that reason, they are not suitable alternatives to CE-UV methods in quality-control laboratories.

\section{EXPERIMENTAL}

\subsection{Instrumentation}

All experiments were performed on an Agilent 3D CE (Waldbronn, Germany) system using ChemStation software, equipped with a diode array detector (DAD), an automatic sample injector, a Peltier temperature controller, and a $25 \mathrm{kV}$ highvoltage power supply. Analyses were carried out on a fused-silica capillary (i.d. $50.0 \mu \mathrm{m}$, total length $48.5 \mathrm{~cm}$, and effective length $40.0 \mathrm{~cm}$ ) in normal mode by applying a voltage of $20 \mathrm{kV}$. Sample injections were made in hydrodynamic mode over 7 seconds under a pressure of 50 mbar. The capillary temperature was set at $35^{\circ} \mathrm{C}$ and the detection was performed at $205 \mathrm{~nm}$. For $\mathrm{pH}$ measurements, a pH meter (Mettler Toledo MA 235, Switzerland) calibrated with commercial standard buffers ( $\mathrm{pH}$ 4.0, 7.2 and 9.4) was employed. Deionized water was prepared using a Barnstead NANOpure Diamond Analytical (USA) ultrapure water system. The running buffer and the samples were filtered through $0.45 \mu \mathrm{m}$ Titan syringe filters (Sri Inc., Eaton Town, NJ, USA).

\subsection{Chemicals}

Standard varenicline tartrate (VT, >\%98) was supplied by Refik Saydam National Public Health Agency. Sodium dihydrogen phosphate $\left[\mathrm{NaH}_{2} \mathrm{PO}_{4} \cdot 2 \mathrm{H}_{2} \mathrm{O}\right]$ and sodium hydroxide $[\mathrm{NaOH}]$ were obtained from Merck (Darmstadt, Germany). Citric acid was obtained from Sigma-Aldrich (St. Louis, MO, USA). Water obtained from the Milli-Q water system (Barnstead, USA) was used for the 
preparation of the buffer. Commercially available tablets $\left(\right.$ CHAMPIX ${ }^{\circledR}$ ) containing $1 \mathrm{mg}$ of varenicline (equal to $1.71 \mathrm{mg}$ of VT) or $0.5 \mathrm{mg}$ of varenicline (equal to $0.85 \mathrm{mg}$ of VT) were purchased from a local pharmacy.

\subsection{Solutions}

Phosphate buffer solution (0.01 M, pH 7) was used to prepare the standard stock solutions. $\mathrm{NaH}_{2} \mathrm{PO}_{4} \cdot 2 \mathrm{H}_{2} \mathrm{O}(1.56 \mathrm{~g})$ was dissolved in water $(900 \mathrm{ml})$ and the $\mathrm{pH}$ was adjusted to 7 by adding 1 $\mathrm{M} \mathrm{NaOH}$ solution. The total volume was made up to $1000 \mathrm{ml}$ by adding water.

\subsection{Stock solutions $\left(1000 \mu \mathrm{g} \mathrm{ml^{-1 }}\right)$}

In order to prepare $1000 \mu \mathrm{g} \mathrm{ml}^{-1} \mathrm{VT}$ and Labetalol hydrochloride solutions, two different volumetric flasks $(25 \mathrm{ml})$ were used. VT $(25 \mathrm{mg})$ was dissolved in phosphate buffer solution $(25 \mathrm{ml})$, whereas Labetalol hydrochloride $(25 \mathrm{mg})$ was dissolved in water $(25 \mathrm{ml})$.

\subsection{Calibration standards}

Calibration standards of VT (1.0, 5.0, 10.0, $20.0,30.0,50.0$, and $60.0 \mu \mathrm{g} \mathrm{ml}^{-1}$ ) were prepared daily from the standard stock solution by appropriate dilution processes with water. Each calibration standard contained $20.0 \mu \mathrm{g} \mathrm{ml}^{-1}$ of Labetalol hydrochloride.

\subsection{Citrate buffer solution ( $40 \mathrm{mM}, \mathrm{pH}$ 6.5) for the $B G E$}

Citrate $(3.84 \mathrm{~g})$ was dissolved in water (100 $\mathrm{ml}$ ) to prepare a $0.2 \mathrm{M}$ citric acid solution. The $0.2 \mathrm{M}$ citric acid solution $(20 \mathrm{ml})$ was transferred into a 100 $\mathrm{ml}$ volumetric flask and the flask was filled to the mark. The $\mathrm{pH}$ of this solution was adjusted to $\mathrm{pH} 6.5$ by using $0.1 \mathrm{M} \mathrm{NaOH}$ solution; then, the volume was made up to $100 \mathrm{ml}$. Thus, a $40 \mathrm{mM}$ citrate buffer (pH 6.5) was prepared and used as the BGE.

\subsection{Tablet (test) solutions}

Ten commercial tablets were weighed in order to determine their mean weight, which were then finely powdered in a mortar. An amount of powdered mass equivalent to one tablet was accurately weighed and transferred to a $25 \mathrm{ml}$ volumetric flask. Phosphate buffer $(20 \mathrm{ml})$ was added to the volumetric flask and sonicated for $15 \mathrm{~min}$ to ensure complete extraction of the active substance. The flask was then filled to volume with phosphate buffer after adding $500 \mu \mathrm{l}$ of the IS stock solution $\left(1000 \mu \mathrm{g} \mathrm{ml}^{-1}\right)$. An aliquot from this solution was filtered through a $0.45 \mu \mathrm{m}$ membrane filter. The final tablet solutions contained 20.0 and $40.0 \mu \mathrm{g} \mathrm{ml}^{-1}$ of varenicline, depending on the pharmaceutical dosage forms (the CHAMPIX ${ }^{\circledR}$ tablets contained either $0.5 \mathrm{or} 1 \mathrm{mg}$ of varenicline) as well as $20 \mu \mathrm{g} \mathrm{ml}^{-1}$ of the IS. The amount of varenicline (according to the labels claims) is equal to 34.2 or $68.4 \mu \mathrm{g} \mathrm{ml}^{-1}$ of $\mathrm{VT}$, respectively.

\subsection{Analytical placebo solutions}

According to the literature, the reported ingredients in the formulation are already known [4]. Microcrystalline cellulose $(10 \%, 100 \mathrm{mg})$, anhydrous dibasic calcium phosphate $(83 \%, 830 \mathrm{mg})$, croscarmellose sodium $(5 \%, 50 \mathrm{mg})$, colloidal silicon dioxide $(\% 1,10 \mathrm{mg})$, and magnesium stearate $(1 \%, 10 \mathrm{mg})$ were weighed and mixed to give $1 \mathrm{~g}$ of the mixture. Approximately 0.1 and $0.2 \mathrm{~g}$ of this bulk mixture were used to prepare the placebo solutions for the two different dosage forms (tablets containing 0.5 and $1 \mathrm{mg}$ of varenicline). Analytical placebo solutions were prepared identically to the tablet solutions.

\subsection{Synthetic tablet solutions}

Synthetic tablet solutions were prepared by adding known amounts of VT stock solutions and IS solutions (final concentrations are $34.2 \mu \mathrm{g} \mathrm{ml}^{-1}$ for VT and $20.0 \mu \mathrm{g} \mathrm{ml}^{-1}$ for IS) to the analytical placebo solutions.

\section{RESULTS AND DISCUSSION}

$\mathrm{CE}$ is a relatively new separation technique compared to traditional techniques such as highpressure liquid chromatography (HPLC) or gas chromatography (GC). It offers attractive features such as high efficiency and resolution, and one of the major advantages that makes it both competitive and a good alternative over other separation techniques is the ability of $\mathrm{CE}$ to separate both charged and neutral molecules [16, 17]. In addition, CE is an easy to use and low-cost method in comparison to HPLC. Even though CE is a good alternative to HPLC for the evaluation of impurity profiles and the enantiomeric purity of a drug, it is rarely applied. This might be because of the reservation of national licensing authorities and the pharmacopeia commissions $[17,18]$. The analysis of active drug compounds in pharmaceutical formulations is a routine process in quality-control 
laboratories and it is important to use precise and accurate analytical techniques to perform the analyses [19]. A pharmaceutical company usually has to measure a large number of quality control samples. Even HPLC is an effective method accepted by pharmacopeias and used frequently in quality control, but recently the term "green chromatography" has become very popular as a result of the hazardous environmental impact of HPLC solvents. The elimination of hazardous substances by substituting them with more benign ones is one of the major aims in green chromatography. The other is a reduction in solvent consumption [20]. However, the solvent alternatives to acetonitrile and methanol are not as cheap as the common solvents, and the transfer from already-developed methods to green chromatography regimes are not so easy for routine applications. At this point, it is good to ask why CE methods are still rarely used in quality-control laboratories.

Knowing physicochemical properties (such as $\mathrm{p} K_{\mathrm{a}}$ ) of analytes is important when developing quantitative CE methods. As the $\mathrm{p} K_{\mathrm{a}}$ of VT is 9.2 at $25^{\circ} \mathrm{C}$, it could be ionized at acidic $\mathrm{pH}$ values and there was an aim to develop a capillary-zone electrophoresis (CZE) method [21]. The separation and run time for a CZE method depends on the composition of the BGE as well as the $\mathrm{pH}$, ionic strength, and viscosity of the electrolyte. Optimization of the BGE composition is critical for developing a CZE method for the separation of impurities or degradation products from the active substance. The purpose of the buffer in CZE is to control the $\mathrm{pH}$, ionic strength, and viscosity. The selection of a buffer is based on the $\mathrm{p} K_{\mathrm{a}}$ value of the compound to be analyzed. The buffer has a maximum buffering capacity at a $\mathrm{pH}$ that is equal to the $\mathrm{p} K_{\mathrm{a}}$ of the buffer. Therefore, various buffers (acetate and phosphate buffers) with acidic $\mathrm{pH}$ values were evaluated in the initial experiments. The best results with regard to the migration time, efficiency, resolution, and peak symmetry were obtained with citrate buffer.

\subsection{Optimization of the $B G E$}

As citric acid has three $\mathrm{p} K_{\mathrm{a}}$ values of 3.14 , 4.75 and 6.40, different BGE $\mathrm{pH}$ values (from $\mathrm{pH}$ 3.5 to 6.5 ) were evaluated. Figure $2 \mathrm{a}$ presents the effect of $\mathrm{pH}$ on the migration times of VT and IS. According to the results shown in Figure 2a, the electroosmotic flow (EOF) was increased and the migration times of VT and IS were shortened [22]. The electrophoretic mobility, the second significant parameter affecting migration times in CZE separations, was decreased as a result of the low amount of positively charged VT and IS molecules at high $\mathrm{pH}$ values [23]. Therefore, $\mathrm{pH} 6.0$ was selected as an optimum value for achieving short analyte migration time and better resolution. Another parameter that could be manipulated in order to change the migration time was the concentration of the BGE. The concentration of $\mathrm{pH} 6.0$ citrate buffer was changed within the range of $10-80 \mathrm{mM}$, and the migration times of VT and IS were shown to increase at higher concentrations. This was an expected result, as seen in Figure $2 b$.

Even though, the migration times were shortened with lower buffer concentrations, a lower buffer concentration might cause adverse repeatability of the method. Thus, a $40 \mathrm{mM}$ buffer concentration was considered as the optimum value.
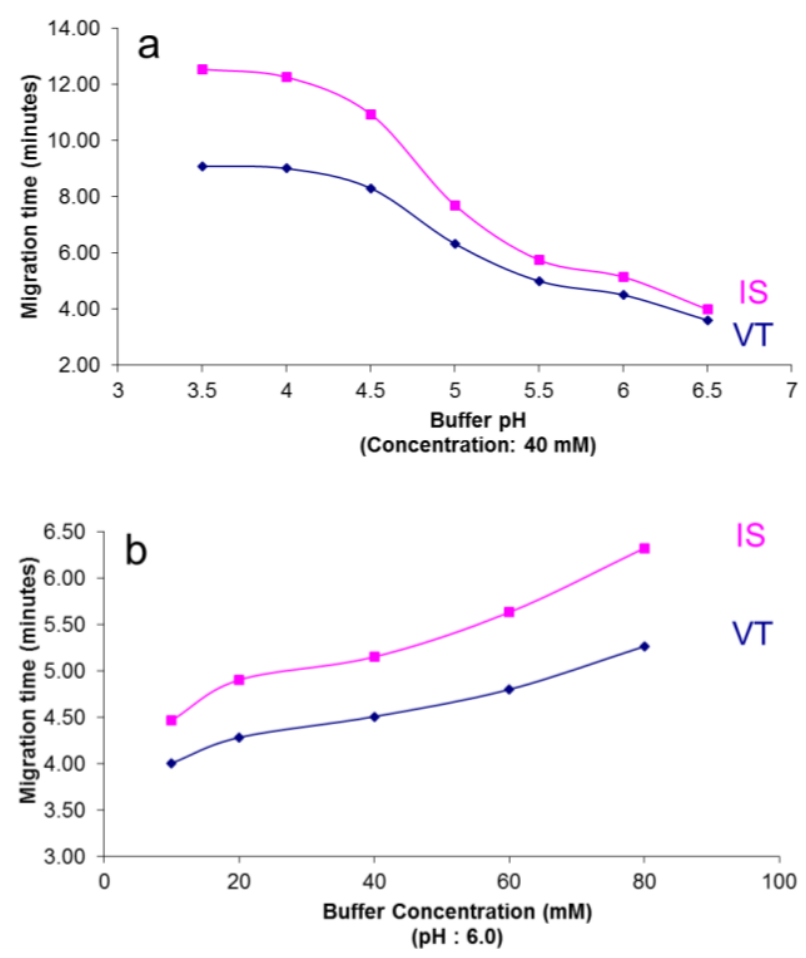

Fig. 2. a) The effect of citrate buffer pH. b) The effect of citrate buffer concentration on the migration time of VT and IS. Experimental conditions: $T=30{ }^{\circ} \mathrm{C}$ (capillary temperature), $V$ $=20 \mathrm{kV}$ (applied voltage), $t_{\text {(inj) }}=4 \mathrm{~s}$ at 50 mbar (hydrodynamic injection), $\lambda=205 \mathrm{~nm}$ (detection wavelength), VT: 20.00 $\mu \mathrm{g} \mathrm{ml}^{-1}$, IS: $20.00 \mu \mathrm{g} \mathrm{ml}^{-1}$

\subsection{Optimization of instrument parameters}

It is known that the apparent mobility $\left(M_{\text {app }}\right)$ is directly related to electroosmotic mobility $\left(M_{\mathrm{EOF}}\right)$ and electrophoretic mobility $\left(M_{\mathrm{e}}\right)$ according to the formula $\left(M_{\mathrm{e}}=M_{\text {app }}-M_{\mathrm{EOF}}\right)$. The applied voltage for the separation can change the migration time by changing the $M_{\mathrm{EOF}}$ and $M_{\mathrm{e}}$ [24]. In addition, the 
capillary temperature would change the $M_{\mathrm{EOF}}$ by changing the viscosity inside the capillary. The use of a maximum capillary temperature and application voltage results in joule heating, which causes peak broadening and a current drop in the capillary [25]. Therefore, the effects of three different application voltages and three different capillary temperatures $\left(15,20\right.$, and $\left.25^{\circ} \mathrm{C}\right)$ on the migration times were evaluated simultaneously. The observed migration times for VT and IS at different application voltages and capillary temperatures are given in Figure 3.
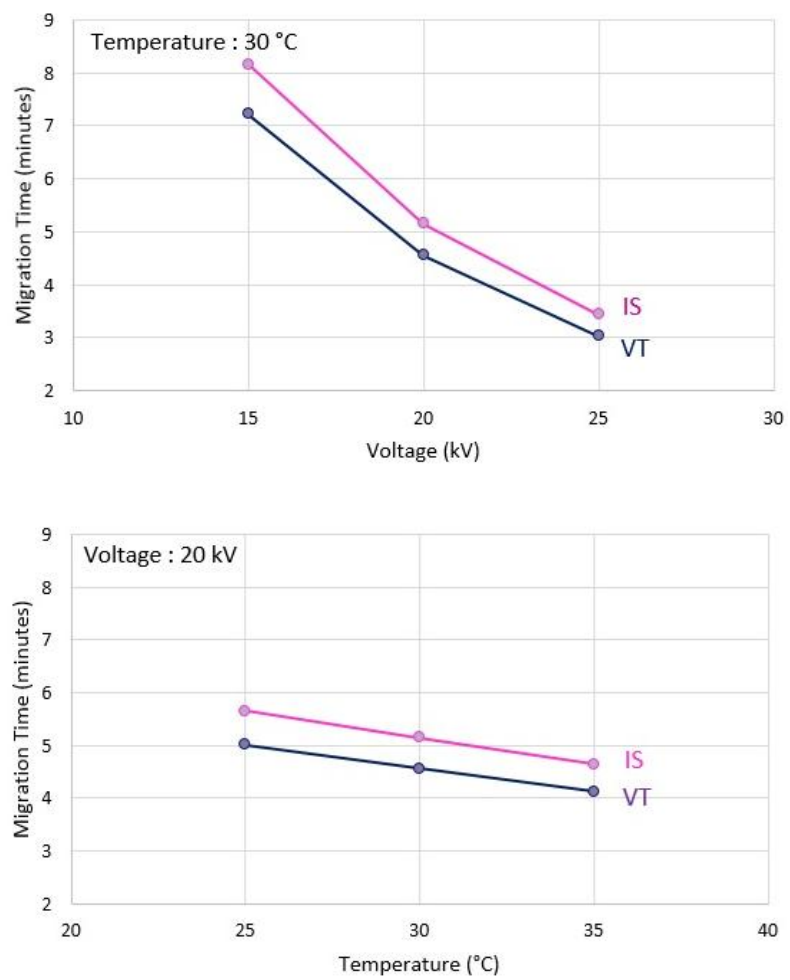

Fig. 3. The effect of instrument parameters on the migration time of VT and IS. Experimental conditions: BGE: citrate buffer ( $\mathrm{pH} 6.0) 40 \mathrm{mM}, t_{\text {(inj) }}=4 \mathrm{~s}$ at $50 \mathrm{mbar}$ (hydrodynamic injection), $\lambda=205 \mathrm{~nm}$ (detection wavelength), VT: $20.00 \mu \mathrm{g} \mathrm{ml}^{-1}$, IS: $20.00 \mu \mathrm{g} \mathrm{ml}^{-1}$

There were short migration times observed at an applied voltage of $25 \mathrm{kV}$ and a capillary temperature of $30{ }^{\circ} \mathrm{C}$, but there was no joule heating observed at an applied voltage of $20 \mathrm{kV}$ with a capillary temperature of $35{ }^{\circ} \mathrm{C}$. The hydrodynamic injections were performed within 1-10 seconds at 50 mbar. It was observed that the peak heights for VT did not increase significantly after an injection of 7 seconds (Fig. 4). As there was no interference coming from matrix components, a wavelength of $205 \mathrm{~nm}$ was used for the analysis. In conclusion, the experimental parameters were considered as $40 \mathrm{mM}$ citrate buffer ( $\mathrm{pH} 6.0$ ), $T=35^{\circ} \mathrm{C}$ (capillary temperature), $V=20 \mathrm{kV}$ (applied voltage), $t_{\mathrm{inj}}=7 \mathrm{~s}$ at 50 mbar (hydrodynamic injection), and $\lambda=205$ $\mathrm{nm}$ (detection wavelength where maximum absorption observed).

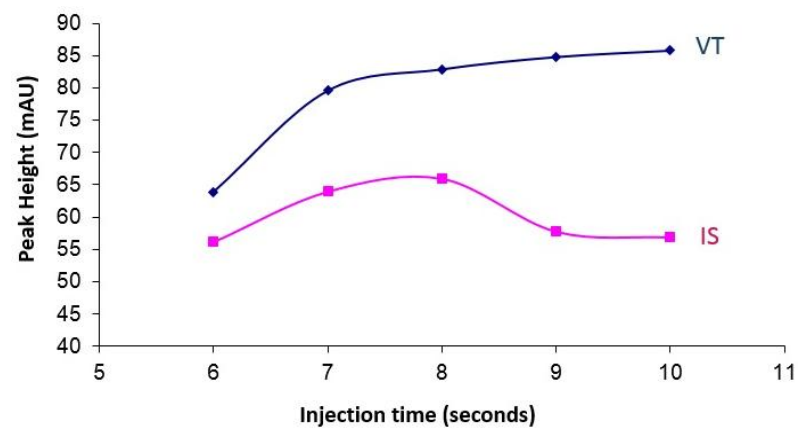

Fig. 4. The effect of injection time (at 50 mbar hydrodynamic injection) on the peak heights of VT and IS. Experimental conditions: BGE: citrate buffer (pH 6.0) $40 \mathrm{mM}, \lambda=205 \mathrm{~nm}$ (detection wavelength), $T=35^{\circ} \mathrm{C}$ (capillary temperature), $V=20 \mathrm{kV}$ (applied voltage), $\lambda=205 \mathrm{~nm}$ (detection wavelength), VT: $20.00 \mu \mathrm{g} \mathrm{ml}^{-1}$, IS: $20.00 \mu \mathrm{g} \mathrm{ml}^{-1}$.

\subsection{Validation of the analytical method}

The proposed method was validated according to the ICH guidelines [26]. The linearity range, sensitivity, repeatability, precision, accuracy, specificity, robustness, and ruggedness of the developed method were investigated.

\subsection{Linearity range and sensitivity}

Solutions of VT were analyzed at different concentrations. In order to perform a relative correction of peak areas as a result of shifting in migration times, calibration curves were established using the ratio of the analyte peak area to the migration time. This ratio enabled peak normalization (PN) for both VT and IS. Thus, the IS method was applied using PN ratios. According to the calculations, the PN ratios were out of the linearity range at concentrations of VT higher than $60 \mu \mathrm{g} \mathrm{ml}$. The calibration curve was constructed by plotting the analyte concentration against the $\mathrm{PN}$ ratios, and it was linear from 1.0 to $60 \mu \mathrm{g} \mathrm{ml}^{-1}$. Hence, eight different concentrations $(1.0,5.0,10.0,20.0,30.0$, $40.0,50.0$, and $60.0 \mu \mathrm{g} \mathrm{ml}^{-1}$ ) of VT were analyzed within the linear range. This process was repeated six times in order to calculate the regression equations. The sensitivity of the analytical method was evaluated by determining the limits of detection (LOD) and quantitation (LOQ). The analyte concentrations at which the signal-to-noise ratios were 3 and 10 were considered the LOD and LOQ, respectively [27]. The results are given in Table 1 . 
Table 1

Linearity of the method $(n=6)$

\begin{tabular}{ll}
\hline \hline & VT \\
\hline Regression equation* & $y=0.0364 x-0.0259$ \\
Standard error of intercept & 0.0047 \\
Standard error of slope & 0.098 \\
Correlation coefficient $(r)$ & 0.9992 \\
Linearity range $\left(\mu \mathrm{g} \mathrm{ml}^{-1}\right)$ & $1.0-60$ \\
Number of data points & 8 \\
LOD $\left(\mu \mathrm{g} \mathrm{ml}^{-1}\right)$ & 0.5 \\
LOQ $\left(\mu \mathrm{g} \mathrm{ml}^{-1}\right)$ & 1.0 \\
\hline
\end{tabular}

$* y=a x+b\left[a\right.$ : intercept, $b$ : slope, $x$ : concentration $\left.\left(\mu \mathrm{g} \mathrm{ml}^{-1}\right)\right]$, $y$ : peak normalization (PN) ratios [PN of VT/ PN of IS]

\subsection{Repeatability}

The repeatability of the developed HPLC method was calculated by ten consecutive injec- tions made with standard solutions containing $30.00 \mu \mathrm{g} \mathrm{ml}^{-1}$ VT. The results were evaluated by considering the retention time and peak area. The method was shown to be highly repeatable, as neither the peak area nor the retention time changed by more than $2 \%$.

\subsection{Precision and accuracy}

Three different standard VT solution concentrations (within the linear range) were analyzed over six consecutive days (inter-day) and each day they were analyzed six times (intra-day). The obtained values for the relative standard deviation (RSD) and the bias of intra- and inter-day studies indicated that the precision and accuracy of the method were satisfactory. The results are summarized in Table 2.

Table 2

Precision and accuracy of the developed method $(n=6)$

\begin{tabular}{|c|c|c|c|c|c|c|c|}
\hline & \multirow[b]{2}{*}{$\begin{array}{c}\text { Added } \\
\left(\mu \mathrm{g} \mathrm{ml}^{-1}\right)\end{array}$} & \multicolumn{3}{|c|}{ Intra-day } & \multicolumn{3}{|c|}{ Inter-day } \\
\hline & & $\begin{array}{l}\text { Found } \\
\left(\mu \mathrm{g} \mathrm{ml}^{-1}\right)\end{array}$ & $\begin{array}{l}\text { Precision } \\
\text { RSD\% }\end{array}$ & $\begin{array}{c}\text { Accuracy } \\
\text { Bias } \%\end{array}$ & $\begin{array}{l}\text { Found } \\
\left(\mu \mathrm{g} \mathrm{ml}^{-1}\right)\end{array}$ & $\begin{array}{c}\text { Precision } \\
\text { RSD \% }\end{array}$ & $\begin{array}{c}\text { Accuracy } \\
\text { Bias } \%\end{array}$ \\
\hline \multirow{3}{*}{ VT } & 3 & $2.95 \pm 0.02$ & 1.5 & -3.3 & $2.86 \pm 0.02$ & 2.1 & -4.7 \\
\hline & 20 & $20.38 \pm 0.22$ & 2.6 & 2.8 & $20.83 \pm 0.08$ & 0.9 & 5.4 \\
\hline & 40 & $39.28 \pm 0.30$ & 1.9 & -3.2 & $40.24 \pm 0.27$ & 1.6 & -1.5 \\
\hline
\end{tabular}

Found: mean \pm standard error $(n=6)$

RSD: Relative standard deviation

Bias: [(found - added) / added] $\times 100$

\subsection{Specificity}

The electropherograms obtained from the standard solutions were identical to those obtained from tablet solutions containing equivalent concentrations of VT. In addition, the analytical placebo and synthetic tablets were analyzed using the developed method. The representative electropherograms (Fig. 5) show that there are no other peaks observed at the retention time of VT and IS. The recovery results for the synthetic tablet solutions were $98.2 \pm 0.9 \%(x \pm \mathrm{SE}$ where $x$ is the mean value and SE is the standard error; $n=6$ ) for
VT. Based on these results, the proposed methods can be considered as being specific.

\subsection{System suitability}

The system suitability test was applied to electropherograms obtained under optimum conditions in order to check various parameters such as the efficiency (plates), peak tailing, resolution, and injection repeatability for the retention time. Suitable resolution (>1.5), efficiency $(>2000)$, and injection repeatability $(<2 \%)$ was achieved for the proposed method, and the total analysis time was within 5 minutes. 


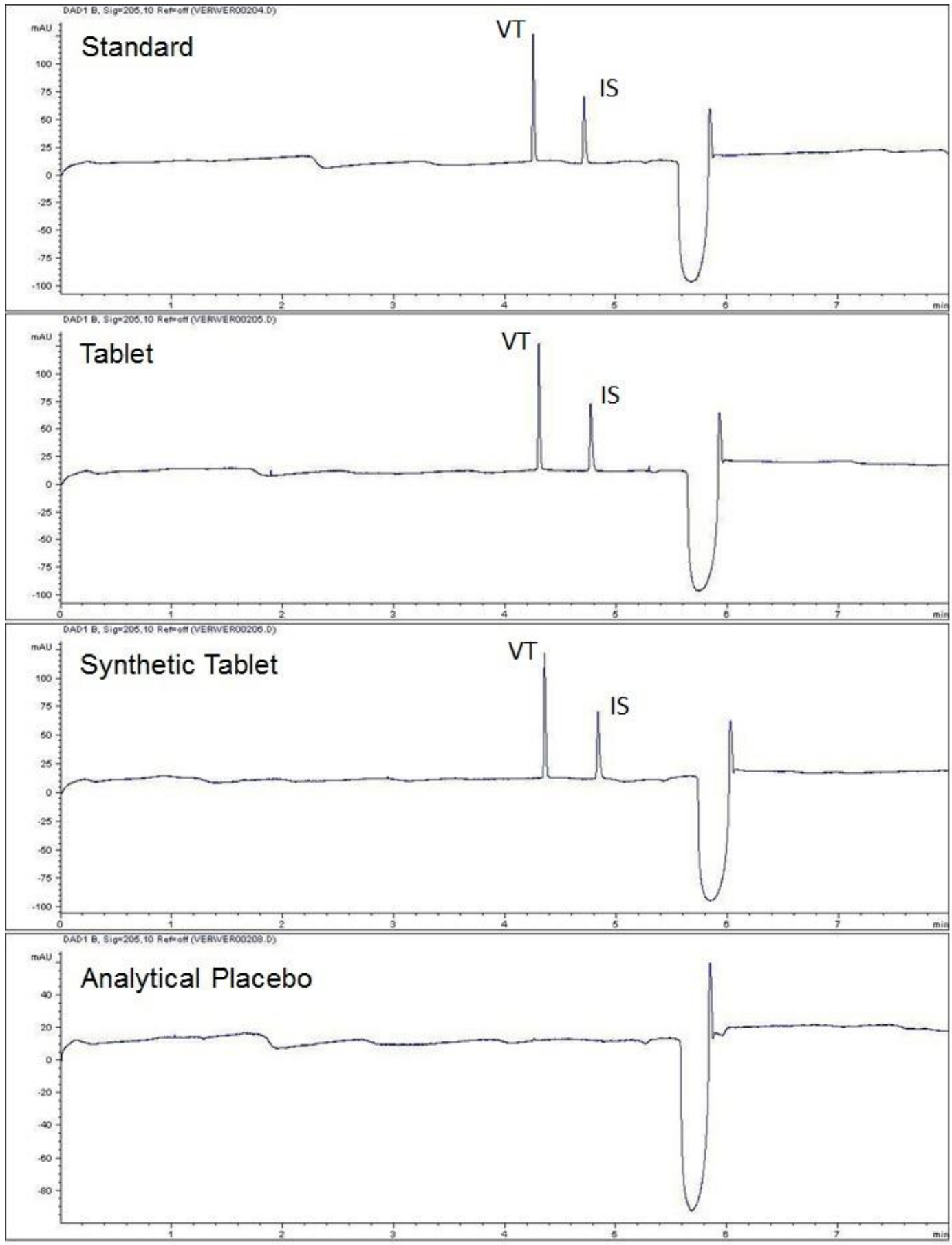

Fig. 5. Electropherograms recorded under optimum conditions. Experimental conditions: BGE: citrate buffer (pH 6.0) $40 \mathrm{mM}, \lambda=205 \mathrm{~nm}$ (detection wavelength), $T=35^{\circ} \mathrm{C}$ (capillary temperature), $V=20 \mathrm{kV}$ (applied voltage), $t_{\text {(inj) }}=7 \mathrm{~s}$ at 50 mbar (hydrodynamic injection), $\lambda=205 \mathrm{~nm}$ (detection wavelength), VT: $34.20 \mu \mathrm{g} \mathrm{ml}^{-1}$, IS: $20.00 \mu \mathrm{g} \mathrm{ml}^{-1}$ for standard, tablet, and synthetic tablet solutions

\subsection{Robustness}

The robustness of an analytical procedure is a measure of its capacity to remain unaffected by small but deliberate variations in method parameters, and it provides an indication of the methods reliability during normal usage. Variations in capillary temperature $\left( \pm 1^{\circ} \mathrm{C}\right)$ and application voltage $( \pm 1 \mathrm{kV})$, in addition to the variations in BGE such as changing $\mathrm{pH}( \pm 0.1)$ and buffer concentration $( \pm 2 \mathrm{mM})$, did not have any significant effect on the response. The PN ratios, which refer to the VT found in the solutions, were changed, relatively, between 97.43 and $103.95 \%$ in comparison to the PN ratios under optimum conditions. Thus, the method is considered robust and the results are not varied by manipulations in the method parameters. The results are given in Table 3. 
T a ble 3

Method robustness test.

Robustness study results upon changing the instrument parameters and composition of BGE, individually and simultaneously $(n=3)$

\begin{tabular}{lccllllrr}
\hline \hline & \multicolumn{9}{c}{ Buffer } & \multicolumn{3}{c}{ VT } \\
\hline & $T\left({ }^{\circ} \mathrm{C}\right)$ & $V(\mathrm{kV})$ & $\begin{array}{l}\text { Conc. } \\
(\mathrm{mM})\end{array}$ & $\mathrm{pH}$ & Manipulation & Added & Found & Recovery $\%$ \\
\hline Optimum & & & & & & & & \\
Conditions & 35 & 20 & 40 & 6.0 & - & & & \\
Condition 1 & 36 & 20 & 40 & 6.0 & $T(+)$ & 34.20 & 34.06 & 99.59 \\
Condition 2 & 34 & 20 & 40 & 6.0 & $T(-)$ & 34.20 & 34.81 & 101,78 \\
Condition 3 & 35 & 21 & 40 & 6.0 & $V(+)$ & 34.20 & 34.59 & 101.14 \\
Condition 4 & 35 & 19 & 40 & 6.0 & $V(-)$ & 34.20 & 35.02 & 102.40 \\
Condition 5 & 35 & 20 & 42 & 6.0 & Conc. $(+)$ & 34.20 & 35.55 & 103.95 \\
Condition 6 & 35 & 20 & 38 & 6.0 & Conc. $(-)$ & 34.20 & 34.19 & 99.97 \\
Condition 7 & 35 & 20 & 40 & 6.1 & pH (+) & 34.20 & 35.18 & 102.87 \\
Condition 8 & 35 & 20 & 40 & 5.9 & pH (-) & 34.20 & 33.92 & 99.18 \\
Condition 9 & 36 & 20 & 42 & 6.0 & $T(+)$, Conc. $(+)$ & 34.20 & 35.44 & 103.63 \\
Condition 10 & 34 & 20 & 40 & 6.1 & $T(-), \mathrm{pH}(+)$ & 34.20 & 34.67 & 101.37 \\
Condition 11 & 35 & 21 & 38 & 6.0 & $V(+)$, Conc. $(-)$ & 34.20 & 35.32 & 103.27 \\
Condition 12 & 35 & 19 & 40 & 6.1 & $V(-), \mathrm{pH}(+)$ & 34.20 & 33.32 & 97.43 \\
\hline \hline
\end{tabular}

Found: The VT concentration found in the samples on different conditions.

\subsection{Ruggedness}

Applying same procedures to two different operators showed the ruggedness of the developed method. The mean values of the results obtained by two different analysts under optimum conditions for $30.0 \mu \mathrm{g} \mathrm{ml}^{-1}$ VT were $29.88 \pm 0.14$ and $30.08 \pm 0.12$, respectively $(n=5)$. When a statistical comparison was performed by the Wilcoxon test, there was no statistically significant difference between these results. Thus, the proposed method is considered rugged.

\subsection{Tablet analysis results}

The assay results of VT in tablet dosage form were comparable with the values claimed on the label (CHAMPIX ${ }^{\circledR}$ tablets contain 0.5 and 1.0 $\mathrm{mg}$ of varenicline). The varenicline concentrations (20.0 and $40.0 \mu \mathrm{g} \mathrm{ml}^{-1}$ ) in the tablet solutions were equal to 34.2 and $68.4 \mu \mathrm{g} \mathrm{ml}^{-1} \mathrm{VT}$, respectively. The results were $0.51 \pm 0.01$ and $1.02 \pm 0.02$ [mean \pm standard error $(n=6)]$ for the tablets containing 0.5 and $1.0 \mathrm{mg}$ of varenicline, respectively. The RSD values were between 3.81 and $3.83 \%$, and the bias ([(found - labeled claim) / labeled claim] $\times 100)$ values were between 1.66 and $2.16 \%$, indicating the suitability of the method for the routine analysis of VT in its pharmaceutical dosage form.
In conclusion, the method was accurate, specific, and sensitive, and it could be proposed for quality-control laboratories. The RSD values for both the tablet analysis and recovery studies were less than $4 \%$, indicating a high degree of precision for the proposed method. The effects of small, but deliberate, changes in the instrument parameters and BGE composition were evaluated as a part of testing for method robustness. The results indicated that the method is robust and is unaffected by small variations in the electrophoretic conditions. Thus, it is now certain that minor changes do not affect the reproducibility of the developed method. The simple procedures of preparing the samples and BGE make this method suitable for routine analysis of a large number of samples per day. Aqueous solutions were used for every part of the analysis and it provides a "green" alternative to chromatographic methods. In addition, the cost of the developed method is lower than the current used methods.

\section{REFERENCES}

[1] G. M. Keating, M. A. Siddiqui, Varenicline: A review of its use as an aid to smoking cessation therapy, CNS Drugs, 20, 945-960 (2006).

[2] K. B. Mihalak, F. I. Carroll, C. W. Luetje, Varenicline is a partial agonist at alpha4beta2 and a full agonist at alpha7 neuronal nicotinic receptors, Mol. Pharmacol., 70, 801-805 (2006). 
[3] R. Niaura, C. Jones, P. Kirkpatrick, Varenicline, Nat. Rev. Drug Discov., 5, 537-538 (2006).

[4] Web Page http://www.rxlist.com/chantix-drug.htm (Accessed: 22.10.2014),

[5] A. A. Kadi, M. S. Mohamed, M. G. Kassem, I. A. Darwish, A validated stability-indicating HPLC method for determination of varenicline in its bulk and tablets, Chem. Cent. J., 5, (2011).

[6] S. S. Pujeri, A. M. A. Khader, J. Seetharamappa, Stress degradation studies on varenicline tartrate and development of a validated stability-indicating HPLC method, Sci. Pharm., 80, 115-126 (2012).

[7] P. Katakam, R. R. Kalakuntla, S. Jaypal Reddy, A novel stability indicating RP-HPLC assay method for the determination of varenicline in pharmaceutical formulations, Pharmacologia, 3, 169-173 (2012).

[8] A. A. Kadi, M. S. Mohamed, M. G. Kassem, I. A. Darwish, A validated stability-indicating HPLC method for determination of varenicline in its bulk and tablets, Chem. Cent. J., 5, 30 (2011).

[9] K. P. Channabasavaraj, J. S. Modiya, H. M. Sharath, Development and validation of RP-HPLC method for estimation of varenicline tartrate in bulk drug and tablet dosage form, Int. J. Pharm. Pharm. Sci., 3, 59-61 (2011).

[10] B. Satheesh, S. Kumarpulluru, V. Raghavan, D. Saravanan, UPLC separation and quantification of related substances of varenicline tartrate tablet, Acta Chromatogr., 22, 207-218 (2010).

[11] E. Kocak, M. Celebier, S. Altinoz, Validation of spectrophotometric method to quantify varenicline content in tablets, Asian J. Chem., 25, 1845-1848 (2013).

[12] M. M. Aleksic, V. Radulovic, N. Lijeskic, V. Kapetanovic, Electrochemical response and determination of varenicline at boron-doped diamond, glassy carbon and hanging mercury electrodes, Curr. Anal. Chem., 8, 133142 (2012).

[13] H. A. Alhazmi, H. A. Makeen, S. El Deeb, Determination of varenicline by capillary zone electrophoresis, Dig. J. Nanomater. Bios., 8, 295-300 (2013).

[14] J. P. Schaeper, M. J. Sepaniak, Parameters affecting reproducibility in capillary electrophoresis, Electrophoresis, 21, 1421-1429 (2000).

[15] J. Piešt’anský, K. Maráková, L. Veizerová, J. Galba, P. Mikuš, On-line column coupled isotachophoresis- capillary zone electrophoresis hyphenated with tandem mass spectrometry in drug analysis: Varenicline and its metabolite in human urine, Anal. Chim. Acta, 826, 8493 (2014).

[16] W. Thormann, J. Caslavska, Capillary electrophoresis in drug analysis, Electrophoresis, 19, 2691-2694 (1998).

[17] L. Suntornsuk, Capillary electrophoresis in pharmaceutical analysis: A survey on recent applications, $J$. Chromatogr. Sci., 45, 559-577 (2007).

[18] U. Holzgrabe, D. Brinz, S. Kopec, C. Weber, Y. Bitar, Why not using capillary electrophoresis in drug analysis?, Electrophoresis, 27, 2283-2292 (2006).

[19] http://www.who.int/medicines/areas/quality_safety/quality_assurance/control/en/index.html,

[20] J. Plotka, M. Tobiszewski, A.M. Sulej, M. Kupska, T. Gorecki, J. Namiesnik, Green chromatography, J. Chromatogr. A, 1307, 1-20 (2013).

[21] S. P. Sudhakar, A. M. A. Khader, J. Seetharamappa, Stress degradation studies on varenicline tartrate and development of a validated stability-indicating HPLC method, Sci. Pharm, 80, 115-126 (2012).

[22] M. A. Hayes, I. Kheterpal, A. G. Ewing, Effects of buffer $\mathrm{pH}$ on electroosmotic flow control by an applied radial voltage for capillary zone electrophoresis, Anal. Chem., 65, 27-31 (1993).

[23] H. Celik, M. Buyukaga, M. Celebier, E. T. Acar, M. S. Baymak, N. Gokhan-Kelekci, E. Palaska, H. Erdogan, Determination of $\mathrm{p} K(\mathrm{a})$ values of some benzoxazoline derivatives and the structure-activity relationship, $J$. Chem. Eng. Data, 58, 1589-1596 (2013).

[24] G. A. Caliaro, C. A. Herbots, Determination of $\mathrm{p} K(\mathrm{a})$ values of basic new drug substances by $\mathrm{CE}, J$. Pharmaceut. Biomed., 26, 427-434 (2001).

[25] X. C. Xuan, D. Q. Li, Joule heating effects on peak broadening in capillary zone electrophoresis, $J$. Micromec. Microeng., 14, 1171-1180 (2004).

[26] ICH Guideline. Q2 (R1): Validation of Analytical Procedure: Text and Methodology. ICH, London; 2005.

[27] A. Shrivastava, V. B. Gupta, Methods for the determination of limit of detection and limit of quantitation of the analytical methods, Chronicles of Young Scientists, 2, 21 (2011). 